\title{
A Meta-Analysis of Contemporary Quality of Educational Management Research
}

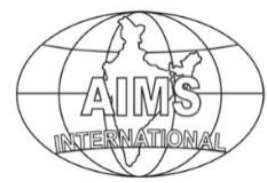

DOI: $10.26573 / 2017.11 .2 .4$

Volume 11, Number 2

May 2017, pp. 135-146

\author{
Yuan-Duen Lee \\ Chiu-Chuan Lin \\ Chen-Fen Huang \\ Chang Jung Christian University \\ (ydlee@mail.cjcu.edu.tw) \\ (cclin@mail.cjcu.edu.tw) \\ (grace821456@gmail.com)
}

\begin{abstract}
The aim of this paper is to identify the key issues in the quality of educational management research, based on co-citation and factor analyses, in order to assess the intellectual structure of this body of literature. By analyzing 58,894 citations in 1,643 articles published in SSCI journals in the field of the quality of educational management between 2004 and 2013, this paper identified the most important publications, scholars and journals. The results can help to profile the network of knowledge production in the quality of educational management research, and so provide important insights with implications for current and future research paradigms, and thus are of value to both management scholars and practitioners.
\end{abstract}

Keywords: Educational Management, Intellectual Structure, Co-Citation Analysis, Meta-Analysis

\section{Introduction}

The Social Sciences Citation Index (SSCI) is used for analysis in this work, as this provides the most comprehensive and widely accepted database for quality of educational management publications.

A generic model of the invisible network of knowledge (INK) (Wang \& Lee, 2007) is applied in this paper to map the intellectual structure of the educational management literature. The aim of this study is thus to provide educational management researchers with a unique way to better understand educational management related publications, and offer a systematic and objective mapping of the different themes and concepts that have emerged in the development of this field.

This study also aims to identify the links among different publications and confirm their statuses and positions with regard to the evolution of the field of educational management. The principal methods used applied are citation and co-citation analysis, as well as social network analysis, which are carried out to identify the invisible network of knowledge generation underlying the educational management literature (Etemad \& Lee, 2003).

\section{Literature Review}

\subsection{Review of the Educational Management Literature}

The education literature contains many studies which state that improving instruction relies on research that not only examines what teachers do in class, but also analyzes 
their perceptions and interpretations of their actions (Bullough, 1991; Joseph \& Burnaford, 2001; Kloss, 1987; Nieto, 1994; Solas, 1992). Obtaining a better understanding what occurs in classrooms thus depends on reflection and analysis of the instruction and interaction that happens in this context by those involved in the actual processes (Dewey, 1938/1997).

Low-performing students may decide to move to another school in order to improve their educational prospects by moving to a better institution (Hanushek et al., 2007; Rumberger et al., 1999), or perhaps such students simple tend to be more transient (Alexander et al., 1996). Moreover, many studies have demonstrated that peer characteristics and quality can affect academic outcomes (Figlio, 2001; Hanushek et al., 2003; Hanushek et al., 2009; Hoxby, 2000; Lefgren, 2004; Zimmer \& Toma, 2000). In short, the quality of both schools and students is very important, with strong impacts.

However, recent research indicates that the link between education and classroom quality is not always found in large-scale national studies, and that policies which focus on simply increasing access to education may not necessarily result in high quality classrooms (Early et al., 2006; Early et al., 2007). Since there is conflicting evidence on the impact of education on classroom quality, it is necessary to identify what criteria of professional development are the most important, and what other factors influence the effectiveness of education and training.

\subsection{Review of the Invisible Network (INK) Literature}

There are various methods that can be applied to study a body of literature. The most commonly used is the simple literature review, which applies a highly subjective approach to structure the earlier work. However, more objective and quantitative techniques have recently become more popular, with the growth in the number of online databases facilitating this work. These methods use author citations, cocitations to study the invisible knowledge network that ties together the written and published works of a given field (Kuo, \& Lee, 2009). These methods are attractive because they are objective and unobtrusive (Garfield, 1979), and a number of studies have used the bibliometric techniques to study the management research literature. For example, Ponzi (2002) identified the most influential authors and studies in the electronic commerce literature by using citation analysis. However, to the best of our knowledge, no similar studies have has been conducted on the educational management literature, and so this work aims to fill this gap by applying citation and co-citation analysis to a representative sample of recent research on educational management, as found in the Social Sciences Citation Index.

\section{Method}

This study obtained an initial sample of published studies related to educational management by examining the SSCI online database, with 58,894 citations being returned. The objective of this study is to focus on 1,643 articles examining various issues related to educational management, published between 2004 and 2013. The researchers used "educational management", "quality education", "school education" as the key words for searching the database.

The research method used in this work is theory-based citation and co-citation analysis. The term bibliometrics refers to the mathematical and statistical analysis of patterns that appear in publications and documents (Diodato, 1994), and citation 
analysis is based on the idea that authors cite papers that are important to the development of their work. By introducing the INK model, the communication process embedded in various publications can be described, which consists of two stages with each having distinct features. This process is then applied to the educational management field for the period 2004-2013.

Citation analysis is first used to find the inter linked nodes from which the most influential publications and scholars can be identified. Co-citation analysis is then applied to map the intellectual structure of educational management studies and to explore the invisible knowledge nodes that have contributed most to this literature, thus also revealing the evolution of the field, showing the knowledge diffusion process, and giving indications as to where it will go in the future.

An invisible network of knowledge is thus defined in this paper as a set of inter linked nodes represented by authors and publications, based on the frequency of citation and the relationships among different publications. Each set of nodes that is found serves a specific purpose for the study of educational management.

In this work, the SSCI is used as the basis for analysis. The SSCI includes all citations published by the leading scholarly journals. While some studies recommend using other online databases for such analysis, the SSCI provides the most comprehensive and the most accepted database of educational management publications, as so it appropriate for this research.

Unlike other studies, the data used in this work were not drawn from journal by peer researchers. In order to map the intellectual structure of educational management studies over the past decade (McCain, 1991), this study proposes using a generic INK model through which the most important publications and influential scholars can be identified, as well as the correlations among these. It then uses 58,894 citations from 1,643 articles published in SSCI journals in the field of educational management area 2004 and 2013 to map an INK of these works.

\subsection{Citation Analysis}

\section{Discussion}

To identify the most important publications and scholars that have laid groundwork for educational management research, citation data were tabulated for educational management research namely for each of the 1,643 source documents and 58,894 references, using MS Excel, with the resulting statistics shown in the following tables. To identify the most important publications and scholars that Table 1 gives the most cited journals in educational management. From 2004 to 2008 the top three were Child Development, Journal of Educational Psychology and Journal of Research in Science Teaching, followed by American Educational Research Journal and Review of Educational Research. It can thus be seen that the most cited journals are educational and management specific ones (see Table 1).

The top three cited journals were Child Development, Journal of Educational Psychology and the Journal of Research in Science Teaching in the first period (2004 2008). However, the number of citations increased in this second period (2009 2013), showing that this field of research was becoming increasingly important (see Table 2).

Looking at these results between the two periods in more details: Comparing these results for the two periods in more detail, we can see citations for Child Development rose from 491 to 1,431; those for the Journal of Educational 
Psychology increased from 348 to 1,485; for the Journal of Research in Science Teaching the number grew from 242 up to 1,265; those for American Educational Research were up from 240 to 865; those for the Review of Educational Research increased from 228 to 1,439; those for Educational Evaluation and Policy Analysis rose from 221 up to 739; those for Higher Education grew from 218 up to 748 and those for Early Childhood Research Quarterly rose from 176 to 1,077. It can thus be seen that the number of citations increased significantly for all these journals.

Table 1 Most Frequently Cited Journals from 2004 to 2008 (Citation Frequency $\geqq 176$ )

\begin{tabular}{|l|c|}
\hline \multicolumn{1}{|c|}{ Journals } & Total Citations \\
\hline Child Development & 491 \\
\hline Journal of Educational Psychology & 348 \\
\hline Journal of Research in Science Teaching & 242 \\
\hline American Educational Research Journal & 240 \\
\hline Review of Educational Research & 228 \\
\hline Educational Evaluation and Policy Analysis & 221 \\
\hline Higher Education & 218 \\
\hline Economics of Education Review & 195 \\
\hline Research in Higher Education & 183 \\
\hline Early Childhood Research Quarterly & 176 \\
\hline
\end{tabular}

Table 2 Most Frequently Cited Journals from 2009 to 2013 (Citation Frequency $\geqq 739$ )

\begin{tabular}{|l|c|}
\hline \multicolumn{1}{|c|}{ Journals } & Total Citations \\
\hline Child Development & 1431 \\
\hline Journal of Educational Psychology & 1385 \\
\hline Journal of Research in Science Teaching & 1265 \\
\hline Review of Educational Research & 1239 \\
\hline Early Childhood Research Quarterly & 1077 \\
\hline Teaching and Teacher Education & 868 \\
\hline American Educational Research Journal & 865 \\
\hline Higher Education & 748 \\
\hline Computers \& Education & 746 \\
\hline Educational Evaluation and Policy Analysis & 739 \\
\hline
\end{tabular}

\subsection{Network Analysis of Authors}

This phase of the analysis attempts to capture the prevalent trends in the literature by examining the relationships among authors. The researchers selected the 10 most highly cited scholars in two different periods, 2004-2008 and 2009-2013, with the result revealed in Tables 3 and 4, respectively.

Table 3 Top Authors from 2004 to 2008 (Citation Frequency $\geqq 49$ )

\begin{tabular}{|l|c|l|c|}
\hline \multicolumn{1}{|c|}{ Author } & Frequency & \multicolumn{1}{c|}{ Author } & Frequency \\
\hline Darling-Hammond L & 165 & Biggs J & 66 \\
\hline Howes C & 130 & Ramsden P & 60 \\
\hline Dewey J & 127 & Slavin RE & 53 \\
\hline Hanushek EA & 121 & Burchinal & 50 \\
\hline Dewey J & 71 & Heyneman SP & 49 \\
\hline
\end{tabular}


Table 4 Top Authors from 2009 to 2013 (Citation Frequency $\geqq 123$ )

\begin{tabular}{|l|c|l|c|}
\hline \multicolumn{1}{|c|}{ Author } & Frequency & \multicolumn{1}{c|}{ Author } & Frequency \\
\hline Hanushek EA & 302 & Marsh HW & 145 \\
\hline Howes C & 204 & UNESCO & 140 \\
\hline Pianta RC & 171 & Ramsden P & 134 \\
\hline Darling-Hammond L & 169 & National Research Council & 127 \\
\hline OECD & 162 & Cohen J. & 123 \\
\hline
\end{tabular}

In the first period (2004-2008), the top three authors were Darling-Hammond L, Howes C and Dewey J. In the second period (2009-2013), these were Hanushek E A, Howes C and Pianta R C. Hanushek EA thus moved fourth place to the first, with the number of citations rising from 121 up to 302. The second most notable scholar was Howes C, with citations rising from 130 to 204.

\subsection{Co-Citation Analysis}

Data was obtained and analyzed, and thus the intellectual structure of recent educational management studies was revealed. Co-citation analysis involves counting documents from a certain field, using paired or co-cited documents. Cocitation analysis compiles co-citation counts in matrix form and then statistically scales them to obtain a snapshot at a certain point in time of what is in fact a changing and evolving structure of knowledge (McCain, 1991).

In this study the co-citations were tabulated for each source document using MS Excel. Many of the authors had very few co-citations, and these were either unlikely to have had a significant impact on the development of the field, or their works were too new to have had time to impact the literature. To facilitate analyses it was thus ensured that all authors in the final set had at least 30 citations in the first five years and 30 in the second five years. Based on the total number of citations in the focal journals, the top scholars were first identified, and a co-citation matrix was then built, with a pictorial map drawn to show the correlations among the various individuals. This was done following the procedures recommended by White and Griffith (1981).

By taking the co-citation matrix and grouping the authors, researchers can see which authors are linked together and therefore share a common element. The closeness of author points in the resulting diagrams is algorithmically related to their similarity, as perceived by the citations. This study used the r-Pearson statistic as a measure of similarity between author pairs, because this registers the similarity in count profiles compared to all the other authors in the set shapes of their co-citation (Garfield, 1979)

\subsection{Findings}

In first period (2004-2008), one key difference in the literature between more and less effective teachers was their affective skills (Emmer et al., 1980). Teachers who show that they care about their students have higher levels of student achievement than those seen by students as uncaring (Collinson et al., 1999; Darling-Hammond, 2000; Hanushek, 1971; Wolk, 2002). Training effective, qualified, and culturally responsive teachers for work in inner-city schools is thus a vital step in developing equitable and just schooling for these students (Bergeron, 2008; Gay, 2000; Villegas \& Lucas, 2002). 
As Ball (1991a) noted, "Teachers cannot help children learn things they themselves do not understand". SMK (Subject Matter Knowledge) is defined as the general conceptual understanding of a subject area that a teacher has, which is obtained by completing the related coursework (Shulman, 1986). However, efforts to directly measure the SMK needed to teach a certain course for a particular age level are rare, and instead, researchers and administrators tend to examine teachers' backgrounds to assess their education(coursework, grades, degrees) or certification (number of certifications, certified subject areas), or look at standardized test scores (Boardman et al.,1977; Ferguson, 1991; Greenwald et al., 1996a, 1996b; Hanushek, 1972, 1996; Harbison \& Hanushek, 1992; Mullens et al., 1996; Rowan et al., 1997; Strauss \& Sawyer, 1986; Tatto et al., 1993). Regardless of how such assessments are made, teacher quality is one of the important factors that affect the quality of education.

Research suggests that the teacher-child relationship is one of the most important factors in children's preschool and kindergarten adjustment (Birch \& Ladd, 1998). The characteristics of child-teacher interactions, such as use the teacher being a source of support and help, are related to improvements in students' performance in early childhood classrooms (Matsumura et al., 2002; Nelson-Le Gall \& Resnick, 1998). It is also necessary to consider the conflict that may be expressed within teacher interactions, such as anger, resistance to connection, and discomfort. Research indicates that teacher-child conflict is associated with a number of negative outcomes, including negative attitudes toward school, academic problems, and behavioral difficulties (Birch \& Ladd, 1998; Howes et al., 2000; Werner \& Smith., 1982). Indeed, studies show that the quality of early teacher-child relationships predicts later teacher-child relationship quality (Howes et al., 2000; O'Connor \& McCartney, 2006). Teacher quality is thus one of the important factors that affect the quality of education, especially in early childhood.

A large number of studies indicate that there are variations in relationship quality across teachers and children, and that the characteristics of the individuals involves are responsible for this. For example, child gender has been shown to influence the quality of the teacher-child relationship, as teachers generally report poorer relationships with boys than girls (Pianta, 1999; Rudasill \& Rimm-Kaufman, 2009). Several other factors at various levels (e.g., student and teacher characteristics, prior relationship experiences, and school factors) may also impact the quality of studentteacher relationships (Birch \& Ladd, 1998; Howes et al., 2000; Saft \& Pianta, 2001). However, overall girls seem to have better relationships and performance than boys in this context.

School fixed effects are also critical, because they can control for certain nonfamily factors in the school environment, such as unseen school-level practices or processes. Students from high-poverty areas often attend low-quality schools, which do not have the resources to improve attendance (Lee \& Loeb, 1995). Although there is little agreement regarding the precise mechanisms underlying peer effects in later childhood and adolescence, some works indicate that direct contact with skilled peers can enhance language, social, and problem-solving skills among less skilled individuals (Harris, 2009)

Research has tended to examine the importance of factors such as class size and peer effects, as seen Hanushek et al., (2003), Hoxby (2000), Krueger (2000), Ehrenberg et al., (2001), and Burtless (1996). Moreover, a lot of the literature in this 
field has focused on the educational attainment of pupils in compulsory schooling, with less attention paid to higher education, although one exception is Bandiera et al., (2010)

A growing number of children enroll in early care and education programs (ECE) each year, and their relationships with teachers are key sources of support for social, emotional, behavioral, and academic development (Howes et al., 2000; Pianta et al., 1997). Other works have examined the impacts of non-parental figure attachment on child development, and shown that this has important effects on cognitive and social development (DE Mulder et al., 2000; Howes, 1997; Howes \& Smith, 1995; Mitchell-Copeland et al., 1997; Rutter \& O’Connor, 1999; Seibert \& Kerns, 2009).

Low-performing students may decide to change schools in order improve their educational situation (Hanushek et al., 2007; Rumberger, et al., 1999) or may simply be more transient (Alexander et al., 1996). Research suggests that parents apply data to select schools and then apply pressure by exiting, or threatening to exit, when school quality is poor (Hanushek et al., 2007; Hastings et al., 2007).

Traditionally, large class sizes (e.g., more than 20 children) are associated with worse outcomes than smaller classes (Mash burn et al., 2008), but very small classes could also be a disadvantage, as the students would have fewer partners with whom to interact. Multilevel analyses have shown that teacher quality is a strong predictor of children's school-readiness skills (Howes, 1997; National Institute of Child Health and Human Development [NICHD] Early Child Care Research Network, 2002; Phillipsen et al., 1997), being more important in this regard than class size, school context, and other related variables.

Program features, such as teacher-child ratios, availability of specialists for consultation, opportunities for in-service professional development, and school climate, all impact teachers' classroom practices (Duda et al., 2004; Green et al., 2006; Howes, 1997; Phillipsen et al., 1997). However, more recent research indicates that the link between education and classroom quality is not consistently found in large-scale national studies, and that policies which only focus on increasing access to education may not always result in higher quality classrooms (Early et al., 2006; Early et al., 2007).

Since there is inconclusive evidence on the impact of education on classroom quality (Early et al., 2006; Early et al., 2007; Howes, 1997), it is important to find what criteria of professional development are the most effective, and what issues influence the effectiveness of education and training. The characteristics of the interactional styles of adults in both home and school contexts may interact, having cumulative effects, compensatory effects, or both on children's acquisition of literacy.

\section{References}

1. Alexander, K. L., Entwisle, D. R., \& Dauber, S. L., 'Children in motion: School transfers and elementary school performance', Journal of Educational Research, 90(1), 1996, 3-12.

2. Ball, D. L., 'Research on teaching mathematics: Making subject matter knowledge part of the equation', In J. Brophy (Ed.), Advances in research on teaching 2, 1991a, 1-47, Greenwich, CT: JAI. 
3. Bandiera, O., Larcinese, V., \& Rasul, I., 'Heterogeneous class size effects: Newevidence from a panel of university students', Economic Journal, 120, 2010, 1365-1398.

4. Bergeron, B. S., 'Enacting a culturally responsive curriculum in a novice teacher', Urban Education, 43, 2008, 4-28.

5. Birch, S.H., \& Ladd, G.W., 'Children's interpersonal behaviors and the teacherchild relationship', Developmental Psychology, 34, 1998, 934-946.

6. Boardman, A. E., Davis, O. A., \& Sanday, P. R., 'A simultaneous equations model of the educational process', Journal of Public Economics, 7, 1977, 23-49.

7. Bullough, R. V., Jr., 'Exploring personal teaching metaphors in preservice teacher education', Journal of Teacher Education, 42(1), 1991, 43-51.

8. Burtless, G. (Ed.), 'Does money matter? The effect of school resources on student achievement and adult success', Washington D.C.: Brookings Institution Press, 1996.

9. Collinson, V., Killeavy, M., \& Stephenson, H. J., 'Exemplary teachers: Practicing an ethic of care in England, Ireland, and the United States', Journal for a Just and Caring Education, 5(4), 1999, 349-366.

10. Darling-Hammond, L., 'Teacher quality and student achievement: A review of state policy evidence', Education Policy Analysis Archives, 8, 2000, 1-47.

11. DeMulder, E. K., Denham, S., Schmidt, M., \& Mitchell, J., 'Q-Sort assessment of attachment security during the preschool years', Developmental Psychology, 36(2), 2000, 274-282.

12. Dewey, J., 'Experience and education', New York: Touchstone. (Original work published 1938), 1997.

13. Diodato, V., 'Dictionary of bibliometrics. Binghamton', NY: Haworth Press, 1994.

14. Duda, M. A., Dunlap, G., Fox, L., Lentini, R., \& Clarke, S., 'An experimental evaluation of positive behavior support in a community preschool program', Topics in Early Childhood Special Education, 24, 2004, 143-155.

15. Early, D. M., Bryant, D. M., Pianta, R. C., Clifford, R. M., Burchinal, M. R., Ritchie, S., et al., 'Are teachers' education, major, and credentials related to classroom quality and children's academic gains in pre-kindergarten?', Early Childhood Research Quarterly, 21, 2006, 174-195.

16. Early, D. M., Maxwell, K. L., Burchinal, M., Bender, R. H., Ebanks, C., Henry, G. T., et al., 'Teachers' education, classroom quality, and young children's academic skills: results from seven studies of preschool programs', Child Development, 78(2), 2007, 558-580.

17. Ehrenberg, R. G., Brewer, D., Gamoran, A., \& Willms, J. D, 'Class size and student achievement', Psychological Science in the Public Interest, 2, 2001, 130.

18. Emmer, E. T., Evertson, C. M., \& Anderson, L. M., 'Effective classroom management at the beginning of the school year', Elementary School Journal, 80(5), 1980, 219-231.

19. Etemad, H., \& Lee, Y., 'the knowledge network of international entrepreneurship: Theory and evidence’, Small Business Economics, 20(1), 2003, 5-23.

20. Ferguson, R. F., 'Paying for public education: New evidence on how and why money matters', Harvard Journal on Legislation, 28, 1991, 458-498. 
21. Figlio, D. N., \& Stone, J. A., 'Can public policy affect private school creamskimming?', Journal of Urban Economics, 49, 2001, 240-266.

22. Garfield, E., 'Citation Indexing: Its Theory and Application in Science, Technology, and Humanities', New York: Wiley, 1979.

23. Gay, G., \& Howard, T., 'Multicultural teacher education for the 21 st century', Teacher Educator, 36(1), 2000, 1-16.

24. Green, B. L., Everhart, M., Gordon, L., \& Gettman, M. G, 'Characteristics of effective mental health consultation in early childhood settings: Multilevel analysis of a national survey', Topics in Early Childhood Special Education, 26, 2006, 142-152.

25. Greenwald, R., Hedges, L. V., \& Laine, R. D., 'The effect of school resources on student achievement', Review of Educational Research, 66, 1996a, 361-396.

26. Greenwald, R., Hedges, L. V., \& Laine, R. D., 'Interpreting research on school resources and student achievement: A rejoinder to Hanushek', Review of Educational Research, 66, 1996b, 411-416.

27. Hanushek, E. A., 'Teacher characteristics and gains in student achievement: Estimation using micro data', American Economic Review, 61(2), 1971, 280288.

28. Hanushek, E. A., 'Education and race: An analysis of the educational production process', Lexington, MA: D. C. Heath, 1972.

29. Hanushek, E. A., Kain, J. F., Markman, J. M., \& Rivkin, S. G, 'Does peer ability affect student achievement?', Journal of Applied Econometrics, 18, 2003, 527544.

30. Hanushek, E. A., Kain, J. F., Rivkin, S. G., \& Branch, G. F., 'Charter school quality and parental decision making with school choice', Journal of Public Economics, 91(5), 2007, 823-848.

31. Hanushek, E. A., Kain, J. F., \& Rivkin, S. G, 'New evidence about Brown v. Board of education: The complex effects of school racial composition on achievement', Journal of Labor Economics, 27(3), 2009, 349-383.

32. Hanushek, E., \& Lindseth, A., 'Schoolhouses, courthouses, and statehouses: solving the funding achievement puzzle in America's public schools', Princeton, NJ: Princeton University Press, 2009.

33. Harbison, R. W., \& Hanushek, E. A., 'Educational performance for the poor: Lessons from rural northeast Brazil', Oxford, UK: Oxford University Press, 1992.

34. Harris, D. N, 'Toward policy-relevant benchmarks for interpreting effect sizes: Combining effects with costs', Educational Evaluation and Policy Analysis, 31(1), 2009, 3-29.

35. Hastings, J. S., Van Weelden, R., \& Weinstein, J., 'Preferences, information, and parental choice behavior in public school choice', (NBER Working Paper No. 12995). Cambridge, MA: National Bureau of Economic Research, 2007.

36. Howes, C., 'Children's experiences in center-based child care as a function of teacher background and adult: child ratio', Merrill-Palmer Quarterly, 43, 1997, 404-425.

37. Howes, C., \& Smith, E. W., 'Children and their care caregivers: Profiles of relationship's', Social Development, 4, 1995, 44-61. 
38. Howes, C., Phillipsen, L. C., \& Peisner-Feinberg, E., 'The consistency of perceived teacher-child relationships between preschool and kindergarten', Journal of School Psychology, 38, 2000, 113-132.

39. Hoxby, C. M., 'Peer effects in the classroom: Learning from gender and race variation ', (NBER Working Paper 7866). Cambridge, MA: National Bureau of Economic Research, 2000.

40. Hoxby, C. M., 'the effects of class size and composition on student achievement: New evidence from natural population variation', Quarterly Journal of Economics, 115, 2000, 239-285.

41. Joseph, P., \& Burnaford, G. (Eds.), 'Images of schoolteachers in America (2nd ed.)', Mahwah, NJ: Lawrence Erlbaum, 2001.

42. Kloss, R. J., 'Coaching and playing right field: Trying on metaphors for teaching', College Teaching, 35(4), 1987, 134-139.

43. Krueger, A. B., 'An economist's view of class size research', In M. C. Wang, \& J. D. Finn (Eds.), how small classes help teachers do their best. Philadelphia: Temple University Center for Research in Human Development in Education, 2000.

44. Kuo, H.Y., \& Lee, Y., 'Current research paradigms in knowledge management studies: Themes, concepts and relationships', Niagara Falls, ASAC 2009.

45. Lee, V. E., \& Loeb, S., 'Where do Headstart attendees end up? One reason why preschool effects fade out', Educational Evaluation and Policy Analysis, 7, 1995, 62-82.

46. Lefgren, L., 'Educational peer effects and the Chicago public schools', Journal of Urban Economics, 56(2), 2004, 169-191.

47. Mashburn, A. J., Pianta, R. C., Hamre, B. K., Downer, J. T., Barbarin, O. A., Bryant, D ,\& Howes, C., 'Measures of classroom quality in prekindergarten and children's development of academic, language, and social skills', Child Development, 79, 2008, 732-749.

48. Matsumura, L. C., Patthey-Chavez, G., Valdes, R., \& Garnier, H., 'Teacher feedback, writing assignment quality, and third-grade students' revision in lower- and higher-achieving urban school', Elementary School Journal, 103, 2002, 3-25.

49. McCain, K. W., 'Mapping economics through the journal literature: An experiment in journal co-citation analysis', Journal of the American Society for Information Science, 42 (4), 1991, 290-296.

50. Mitchell-Copeland, J., Copeland, S., Denham, S. A., \& DeMulder, E., 'Childteacher attachment and social competence', Early Education and Development, 8, 1997, 27-39.

51. Mullens, J. E., Murnane, R. J., \& Willett, J. B., 'the contribution of training and subject matter knowledge to teaching effectiveness: A multilevel analysis of longitudinal evidence from Belize', Comparative Education Review, 40, 1996, 139-157.

52. National Institute of Child Health and Human Development (NICHD) Early Child Care Research Network, 'Child care structure-process-outcome: Direct and indirect effects of child care quality on children's development', Psychological Science, 13, 2002, 199-206. 
53. Nelson-Le Gall, S., \& Resnick, L, 'Help seeking, achievement motivation, and the social practice of intelligence in school', In S. A. Karabenick (Ed.), Strategic help seeking: Implications for learning and teaching, 1998, 39-60. Hillsdale, NJ: Erlbaum.

54. Nieto, S., 'Lessons from students on creating a chance to dream', Harvard Educational Review, 64, 1994, 392-426.

55. O'Connor, E., \& McCartney, K., 'Testing associations between young children's relationships with mothers and teachers', Journal of Educational Psychology, 98, 2006, 87-98.

56. Phillipsen, L. C., Burchinal, M. R., Howes, C., \& Cryer, D, 'The prediction of process quality from structural features of child care', Early Childhood Research Quarterly, 12, 1997, 281-303.

57. Pianta, R. C., 'Enhancing Relationships: Between Children and Teachers', Washington, DC: American Psychological Association, 1999.

58. Pianta, R.C., Nimetz, S. L., \& Bennett, E., 'Mother-child relationships, teacherchild relationships, and school outcomes in preschool and kindergarten', Early Childhood Research Quarterly, 12, 1997, 263-280.

59. Ponzi, L. J., 'the intellectual structure and inter disciplinary breadth of organization or industry: A bibliometric study of its early stage of development', Scient to metrics, 55, 2002, 259-272.

60. Rowan, B., Chiang, F., \& Miller, R. J., 'Using research on employees' performance to study the effects of teachers on students' achievement', Sociology of Education, 70, 1997, 256-284.

61. Rudasill, K. M., and S. E. Rimm-Kaufman., 'Teacher-Child Relationship Quality: The Roles of Child Temperament and Teacher-Child Interactions', Early Childhood Research Quarterly, 24(2), 2009, 107-120.

62. Rumberger, R. W., Larson, K. A., Ream, R. K., \& Palardy, G. J., 'The educational consequences of mobility for California students and schools', Policy Analysis for California Education (PACE), 1999.

63. Rutter, M., \& O'Connor, T. G., 'Implication of attachment theory for child care policies', In J. Cassidy, \& P. Shaver (Eds.), Handbook of attachment theory and research 1999, 823-844. New York, NY: Guilford.

64. Saft, E.W., \& Pianta, R. C., 'Teachers' perceptions of their relationships with students: Effects of child age, gender, and the ethnicity of teachers and children', School Psychology Quarterly, 16, 2001, 125-141.

65. Seibert, A. C., \& Kerns, K. A, 'Attachment figures in middle childhood', International Journal of Behavioral Development, 33(4), 2009, 347-355.

66. Shulman, L, 'those who understand: Knowledge growth in teaching', Educational Researcher, 15, 1986, 4-14.

67. Solas, J., 'Investigating teacher and student thinking about the process of teaching and learning using autobiography and repertory grid', Review of Educational Research, 62, 1992, 205-225.

68. Strauss, R. P., \& Sawyer, E. A., 'Some new evidence on teacher and student competencies', Economics of Education Review, 5, 1986, 41-48.

69. Tatto, M. T., Nielsen, H. D., Cummings, W., Kularatna, N. G., \& Dharmadasa, K. H., 'Comparing the effectiveness and costs of different approaches for educating primary school teachers in Sri Lanka', Teaching and Teacher Education, 9, 1993, 41-64. 
70. Villegas, A. M., \& Lucas, T., 'Preparing culturally responsive teachers: Rethinking the curriculum', Journal of Teacher Education, 53, 2002, 20-32.

71. Wang, T.T., \& Y. Lee., 'an invisible network knowledge production of international business management studies: From knowing nothing to knowing something', Ottawa, Ontario, ASAC 2007.

72. Werner, E., \& Smith, E., 'Vulnerable but invincible', New York: Wiley, 1982.

73. White, H., \& B. Griffith, 'Author co-citation: A literature measure of intellectual structure', Journal of the American Society for Information Science, 32(3), 1981, 163-171.

74. Wolk, S., 'Being good: Rethinking classroom management and student discipline', Portsmouth, NH: Heinemann, 2002.

75. Zimmer, R. W., \& Toma, E. F., 'Peer effects in private and public schools across countries', Journal of Policy Analysis and Management, 19(1), 2000, 75-92.

\section{About Our Authors}

Yuan-Duen Lee is a professor at Graduate School of Business and Operations Management, Chang Jung Christian University in Taiwan. He received his BS in Mechanical Engineering and MBA in Industrial Management from National Chang Kung University in Taiwan; MBA in Business Management from Oklahoma City University and $\mathrm{PhD}$ in Educational Management and Human Resource Management from Drake University, USA. His research has covered the fields of Organizational Theory and Management, Educational Management, Leadership, Strategic Management, Innovation and Knowledge Management. He has published seven books and 140 international / domestic journal papers. He has also presented 350 international / domestic conference papers. He served as several Department Chair, Director of Graduate School, Dean of Academic Affairs, Dean of College of Management.

Chiu-Chuan Lin is an associate professor at the Graduate School of Business and Operations Management in Chang Jung Christian University in Taiwan. She received MS and PhD degrees from the Department of Computer Science and Information Engineering in National Taiwan University, Taiwan. Her research area and interests include management of technology, innovation, human resource management, electronic commerce and management information system.

Chen-Fen Huang is a doctoral candidate of Graduate School of Business and Operations Management, Chang Jung Christian University in Taiwan. She received her BA in Accounting, Feng Chia University and Institute of Business Management, National Kaohsiung University of Applied Sciences in Taiwan. She has published several international / domestic journal papers, and several international / domestic conference papers. Her research interests cover Organizational Behavior, Educational Management, and Human Resource Management. 